\title{
China's role in world cotton and textile markets: a joint computable general equilibrium/partial equilibrium approach ${ }^{1}$
}

\author{
Stephen MacDonald ${ }^{\mathrm{a}}$, Suwen Pan ${ }^{\mathrm{b}, *}$, Agapi Somwaru ${ }^{\mathrm{a}}$ and \\ Francis Tuan ${ }^{\mathrm{a}}$ \\ "Department of Agriculture, Economics Research Service, 1800 M Street \\ NW, Washington, DC, 20036-5831 \\ ${ }^{\mathrm{b}}$ Texas Tech University', Agricultural Economics, Agriculture Science \\ Building, Lubbock, 79409 US
}

Under the Uruguay Round's Agreement on Textiles and Clothing (ATC), the quotas inherited from the Multifibre Arrangement were gradually phased-out between January 1995 and 31 December 2004. This study estimates the impact of the ATC's implementation on China's textile industry and China's cotton sector. The study finds that, assuming equilibrium levels of income and exchange rates, the adoption of ATC are expected to increase China's net apparel exports, textile production, cotton consumption, cotton production and cotton imports. However, this study fails to support the hypothesis that the adoption of the ATC results in China supplanting the textile industries of the rest of the developing world. The impacts on cotton are also smaller than indicated by previous studies. These outcomes are somewhat sensitive to estimates of expected efficiency gains around the world.

\section{Introduction}

There are many factors influencing world textile and apparel (T\&A) trade. Consumption of clothing is more income and price responsive than food, for example. International cross-sectional analysis has shown clothing expenditure has an income elasticity of about 0.9 while food has an income elasticity of 0.1 to 0.3 in high-income countries such as the US, Japan and the EU (Seale et al., 2003). Similar results were found for price elasticity.
Time series analysis of US textile trade suggests an even higher responsiveness for imports of cotton products. Sanford (1989) found the volume of US cotton textile imports had an elasticity of 3.1 with respect to real exchange rates and 3.3 with respect to an index of economic indicators from the US Department of Commerces Bureau of Economic Analysis.

Textile and apparel imports by the United States, which is by far the world's as well as China's largest importer, have grown significantly in recent years

*Corresponding author. E-mail: S.pan@ttu.edu

I The views expressed in this publication are those of the authors and do not necessarily reflect the views of USDA and Texas Tech University. 
due to several factors such as China's accession to the WTO, initial phases of liberalization under the Agreement on Textiles and Clothing (ATC) and a period of unusually strong US exchange rates.

Global T\&A trade has been affected by quotas and other impediments for decades, with the MFA affecting about $40 \%$ of world apparel trade (Cline, 1990). While the United States and the European Union (EU) were mandated by the ATC to remove their MFA quotas by 2005 , developing countries are also obliged under the ATC to remove T\&A import barriers incompatible with the General Agreement on Tariffs and Trade (GATT). Many developing countries maintain nontrival trade barriers for T\&A. Thus, while developing countries will benefit from the opportunity to increase their exports to the United States, Canada and the EU, their textile industries could also face import competition in their home markets under the ATC's provisions.

While under the MFA, the T\&A industries of some developing countries were indirectly protected by MFA quotas. For decades, when quotas restrained exports from highly competitive countries, outward foreign direct investment by firms in these countries transferred resources to expand the export capacity of new exporting countries. These new exporters initially had smaller T\&A industries, and were not restrained by quotas. Thus, the quotas sometimes diverted investment in textile capacity away from successful exporting countries and into other countries that otherwise would be producing and exporting substantially less. Typically, quotas were eventually imposed on these countries, although some entered into preferential trade agreements with the United States or the EU. But in either case, a garment assembling industry was established there that was indirectly protected by the MFA.

China, on the other hand, saw its exports significantly constrained by the MFA for many years. There has been substantial foreign investment in China, but not in order to take advantage of preferential treatment for China's exports. In fact, with the end of the MFA, many are concerned that China's T\&A sector might overwhelm the textile industries of other developing countries as well as those in the developed world once textile trade is fully liberalized (Yi, 2003; Yang and Montfort, 2004).

In marked contrast with textile trade, world cotton trade is relatively unencumbered by tariffs and other trade barriers. However, as an input into textile production, cotton trade could be substantially altered by the indirect effects of changes in world T\&A trade policies. As cotton T\&A trade policies determine the location of textile production they in turn also determine the destination of cotton imports, or even if any imports are necessary at all (MacDonald et al., 2001). Just as China is the world's largest producer and exporter of textiles, it is frequently the largest importer of cotton. Furthermore, the volatility of China's cotton imports only heightens the importance of China to world cotton prices. World cotton prices have been highly correlated with China's net cotton imports for decades, and changes in China's textile output can ultimately drive world cotton prices and production.

The objective of the study is to analyze the impacts of the the ATC's implementation on China's textile industry and China's cotton sector. In particular, we test the hypothesis that the ATC's implementation will drive China to supplant the textile industries of the rest of the developing world. There are several studies available to date on the effect of the ATC's phase-out of the MFA on China's T\&A trade, but not all these studies provide insights on the impact of China's textile production, and almost none address cotton (see Table 1 for summary). Recently, studies by Andramananjara et al. (2004) and Nordăs (2004) discussed the impact of removing quotas on clothing exports to developed countries, both indicating that China's exports to the United States could increase significantly with the removal of quotas. Francois and Spinanger (2004) focused on a methodology for measuring the level of protection faced by China and other exporters under the pre-2005 quota system, but did not address the implications of removing this protection. Rivera et al. (2004), using a static, global CGE methodology, estimated that China's clothing exports would rise more than $100 \%$ with the removal of the MFA quotas, but did not include the impact on China's textile production in their analysis. There are also several authors who evaluated the effects on other countries such as India (Chaudhary et al., 2006).

Several earlier studies (Hertel et al., 1996; Yang et al., 1997 and Francois and Spinanger, 2001) used largely the same methodology as Rivera et al., and determined that, with the end of the quotas system, China's textile production would rise from $6 \%$ to $43 \%$, depending on their assumptions. Francois and Spinanger's estimates ranged from $6 \%$ change, found using the standard Global Trade Analysis Project (GTAP) data, to $43 \%$ when an exogenous $10 \%$ cost advantage for production in China was incorporated into their analysis. The remaining studies estimated changes ranging from 6 to $16 \%$. Fang and Babcock (2003) examined likely impacts of clothing quota removal on China's cotton sector, but based their analysis on an assumption that textile production would increase from 20 to $30 \%$. 
Table 1. Previous estimates of the effect of MFA phase-out on China's textile industry

\begin{tabular}{|c|c|c|c|}
\hline Source & Assumptions & Method & Results \\
\hline Andriamananjara, 2004 & $\begin{array}{l}\text { US MFA quotas on } \\
\text { China equal to } \\
\text { a } 20 \% \text { tariff }\end{array}$ & $\begin{array}{l}\text { Reduced form market } \\
\text { share equation for } \\
\text { United States' imports }\end{array}$ & $\begin{array}{l}\text { Elasticity between } \\
\text { quota tariff- } \\
\text { equivalence and } \\
\text { import share is } \\
1.5 \text { to } 3.9\end{array}$ \\
\hline Fang and Babcock, 2003 & $\begin{array}{l}\text { Textile production rises } \\
20 \text { to } 30 \% \text { with WTO } \\
\text { accession }\end{array}$ & $\begin{array}{l}\text { PE, global: parameters } \\
\text { estimated with } \\
\text { 1981-2000 data }\end{array}$ & $\begin{array}{l}\text { China's cotton } \\
\text { production } \\
\text { rises } 4-5 \%\end{array}$ \\
\hline Francois and Spinanger, 2001 & $\begin{array}{l}\text { US MFA quotas on } \\
\text { China equal to a } 33 \% \\
\text { tariff }\end{array}$ & $\begin{array}{l}\text { CGE, global, static: } \\
\text { GTAP database } \\
\text { (V.4) and model }\end{array}$ & $\begin{array}{l}\text { China's textile } \\
\text { production rises } 6 \% \\
\text { (when a } 10 \% \text { cost } \\
\text { advantage for China's } \\
\text { industry is added, } \\
\text { textile production } \\
\text { rises } 43 \% \text { ) }\end{array}$ \\
\hline Francois and Spinanger, 2004 & $\begin{array}{l}\text { Constant elasticity of } \\
\text { substitution import } \\
\text { demand; relative } \\
\text { expenditure weights } \\
\text { are comparable across } \\
\text { OECD countries }\end{array}$ & $\begin{array}{l}\text { Reduced form market } \\
\text { share equation for } \\
\text { developed country } \\
\text { imports }\end{array}$ & $\begin{array}{l}\text { US MFA quotas on } \\
\text { China equal to } \\
\text { a } 25 \% \text { tariff }\end{array}$ \\
\hline Hertel et al., 1996 & $\begin{array}{l}\text { US MFA quotas on } \\
\text { China equal to a } 40 \% \\
\text { tariff }\end{array}$ & $\begin{array}{l}\text { CGE, global, static: } \\
\text { GTAP database (V.2) } \\
\text { and model; elasticities } \\
\text { of substitution } \\
\text { doubled }\end{array}$ & Textile output up $5.9 \%$ \\
\hline Nordas, 2004 & $\begin{array}{l}\text { Quota rents shared } \\
\text { between importing } \\
\text { and exporting coun- } \\
\text { tries; US MFA quotas } \\
\text { equal to a } 20 \% \text { tariff }\end{array}$ & $\begin{array}{l}\text { CGE, global, static: } \\
\text { GTAP database (V.5) } \\
\text { and model }\end{array}$ & $\begin{array}{l}\text { China's share of US } \\
\text { clothing imports } \\
\text { triples to } 50 \% \text {; share } \\
\text { of EU imports little } \\
\text { changed at } 12 \%\end{array}$ \\
\hline Rivera et al., 2004 & $\begin{array}{l}\text { US MFA quotas on } \\
\text { China equal to a } 33 \% \\
\text { tariff }\end{array}$ & $\begin{array}{l}\text { CGE, global, static: } \\
\text { GTAP database (V.5) } \\
\text { and model }\end{array}$ & $\begin{array}{l}\text { China's textile imports } \\
\text { rise } 18 \% \text {, exports } 8 \% \text {. } \\
\text { China's clothing } \\
\text { exports rise } 104 \%\end{array}$ \\
\hline Yang, 1997 & $\begin{array}{l}\text { US MFA quotas equal } \\
\text { to a } 40 \% \text { tariff }\end{array}$ & $\begin{array}{l}\text { CGE, global, static: } \\
\text { GTAP database (V.2) } \\
\text { and model }\end{array}$ & $\begin{array}{l}\text { China's textile } \\
\text { production rises } 16 \%\end{array}$ \\
\hline
\end{tabular}

Of these previous studies, only Fang and Babcock examined cotton either from an agricultural perspective or with respect to competition with other fibers in China's textile industry. None of the previous studies used a dynamic computable general equilibrium (CGE) model, and most address only China peripherally. Dynamic models are better at capturing the long-run effects of policy reform by incorporating changes in investment and capital accumulation. As a result, these simulations include changes in the growth of factor productivity, which can magnify the effects of trade policy reform (Romer, 1984). This study adds to the literature on global analysis of the impact of textile quotas under the MFA, but makes it primary contribution in its analysis of the world's largest clothing, textile and cotton producer, China. Furthermore, this study differs from previous efforts in its more developed focus on the interaction between textiles, cotton and man-made fiber in the worlds largest producer of all three products.

\section{Methodology}

This article analyzes China's textile industry and its impact on China's cotton industry by examining alternative scenarios of the end of the MFA quotas and other trade restrictions per provisions of the ATC. A dynamic CGE model (Diao and Somwaru $2000,2001)$ was used to analyze how the global 
restructuring of $\mathrm{T} \& \mathrm{~A}$ production and consumption worldwide would be expected to change production by China's textile industry. An econometric partial equilibrium model of China's agricultural sector (Pan et al., 2004) was used to examine the impact of changing demand by the textile industry on China's cotton consumption, its regional cotton production and its cotton trade. The study brings together these two models, relying on the CGE model's global economy-wide coverage to capture the changes in the world economy that guide the development of China's textile industry in the post-MFA world, and relying on the econometric model to analyze the response of China's agricultural sector to the growth in its textile industry. Figure A1 presents the linkage between the results of the CGE model and the PE model.

The CGE model used in this study is based on the neoclassical growth theory, and is a dynamic CGE model with multi-regional and multi-sectoral specification. Any exogenous parameter, such as productivity coefficient or labor supply growth rate, can generate growth along steady state path but cannot be endogenously affected by policy variables. Hence, the exogenous steady-state growth, associated with changes in any exogenous parameter, is ignored in the model. However, transitional growth, associated with dynamic adjustment in investment and capital accumulation caused by changes in policy variables, can be observed and will be analyzed in this article. The model includes sectors such as consumption/savings, firms and investment, foreign capital and debt and steady-state conditions in different countries.

We first group exporting countries based on whether or not trade is restrained under the MFA. Specifically, the countries/regions whose exports are restrained by the MFA include: (1) China, (2) India, (3) much of Southeast Asia (Indonesia, Thailand and Malaysia), (4) the Middle East, (5) former Soviet Union countries, (6) the Latin American countries (excluding Mexico and the Caribbean countries) and (7) other South and Southeast Asian countries. On the other hand, the following regions are treated as free from restraint, due to preferential trade agreements: (8) North African and East European countries, (9) other African countries (representing the developing countries free from restraint in the EU market), and (10) Mexico and Caribbean countries, (representing the countries free from restraint in the North American markets).

The study also includes the following industrial countries as major importers and exporters in the world, including two restraining regions: (11) North America (US and Canada), (12) the EU, and two nonrestraining regions: (13) Australia and New Zealand, and (14) Japan, Taiwan, Hong Kong and Korea.

Using the CGE model, we simulate the possible effect of MFA phase-out by improving the efficiency of textile and apparel exports from the countries/ regions restrained by MFA (countries/regions included in (1)-(6)). This necessitates thinking about the relationship between textile output and fiber use. Growing textile production requires a greater amount of inputs, including liber, and it is assumed that changes in textile production can be translated on a one-to-one basis into changes in demand for fiber in China. While data to test this hypothesis are not readily available, it intuitively fits with some textilespecific expectations for the impact of trade reform. The increases in China's textile production simulated by the CGE model are changes in value, and partially reflect higher textile prices. However, the fiber content per dollar of production could increase with the end of the MFA. One widely predicted and documented impact of quantitative restrictions on apparel trade is that exporters upgrade to higher priced products (Krishna and Tan, 1998). Therefore, free trade would result in a shift to lower-priced products with more fiber per dollar by China's textile exporters and producers. The assumption used here is that the shift in quality is exactly the same and opposite to liberalization-induced increase in price, so that the change in the volume of fiber used is the same as the change in the value of output.

The next step in this analysis is to utilize the CGE model's estimated change in China's textile output in a simulation with the partial equilibrium econometric model. Based on the results of the CGE analysis, and the remaining variables in the model are allowed to freely adjust, completing the counter-factual scenario. While the CGE model assumes forward looking economic agents optimizing over a long time span (a 50 year time horizon), this study generally only examines likely impacts on China and the world over the decade following 2004. This shorter time horizon is considered to be long enough to permit significant adjustments and investment in response to the policy changes, but short enough to ensure that other unexpected developments do not invalidate the results.

In the PE model, China's cotton is modelled as a sector in a global comprehensive supply and demand framework, which includes China, the United States, the EU, Africa and 20 other countries and regions. Major components of the cotton model include a supply sector, a demand sector, price linkage equations, manmade fiber production and a textile output equation. 
Area sown to cotton is modelled in a two-stage framework. The first stage determines gross cropping area. The second stage uses economic variables (expected net returns) to determine cropping patterns (area allocation) for cotton and major substitute crops. China's cotton production occurs in three regions: (1) the Yellow River or North China Plain, including Henan and Shandong; (2) the Yangtze River region, including Jiangsu and Anhui; and (3) the Northwest, primarily accounted for by Xinjiang. The partial equilibrium model allows each of these regions to be simulated separately, with separate cropping pattern and yield equations. Perfect price transmission is assumed between national and regional level prices. Major competing crops are as follows: rice in Yangtze River region; soybeans and corn in the Yellow River region; and corn in the Northwest.

Cotton consumption is also modelled in two stages: total domestic fiber consumption and cotton's share of the fiber consumption. After two decades of rapid development, China has emerged as the world's largest producer of man-made fiber. Since 1997, consumption of chemical fiber has grown rapidly and has overtaken that of cotton. The share of cotton in total yarn production has declined from $86 \%$ in 1982 to about $60 \%$ in recent years (Fig. 4). In this model, the weighted fiber price (cotton, wool and polyester) and GDP per capita determine the total fiber consumption, and the price ratio of cotton and other fibers is used to determine the shares of cotton and man-made fiber. Prices for both polyester (as a representative for man-made fibers) and the world cotton price (A-index) are endogenous and determined by world net trade. China's domestic cotton price is also determined by the domestic production, consumption, net trade and ending stocks in the partial equilibrium model (Pan et al., 2004).

\section{Data}

The data for the intertemporal CGE model used in this study are from the GTAP database version 6 , pre-release 1 (GTAP, 2003), including data about trade flows around the world and production and consumption in each country/region in 2001. The original data set includes 85 countries/regions and 57 aggregate sectors. For this study, we aggregate the data into 14 countries/regions (see below) and 7 sectors, including cotton, other crops, livestock, processed food, textiles, apparel and an aggregated manufacturing and services sector. The CGE model used incorporates global, bilateral T\&A trade. Historical trends suggest that world T\&A trade can be expected to grow, and hence change in the world market structure may continue regardless of trade policy changes (Cline, 1990). Similarly, world T\&A trade fluctuates in response to shorter-term macroeconomic factors, like periods of unusually strong or weak income growth (Cline, 1990).

In the partial equilibrium model, the historic and predicted macro variables (real GDP, exchange rate, population and GDP deflator) are from the Food and Agricultural Policy Research Institute (FAPRI). Cotton production, consumption, ending stock, import and export data are from USDA's Production, Supply \& Distribution (PSD) database. The fiber mill consumption and man-made fiber data are from FAO World Fiber Consumption Survey (before 1994), Fiber Organon (after 1994) and from personal contacts in different countries.

\section{Results}

The results from CGE model are presented in Figs 1-5 and Tables 2-4. World T\&A trade increases in the CGE model due to the implementation of the
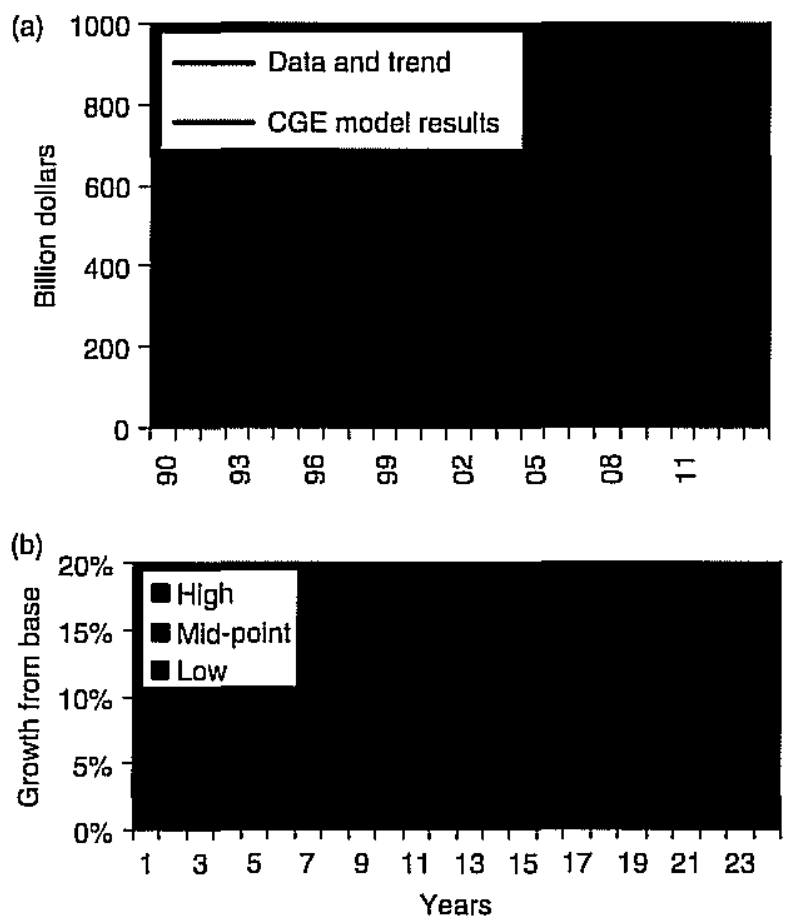

Fig. 1. (a) Gain in world apparel trade under alternative growth scenarios (b) World T\&A trade data/trend and model results 


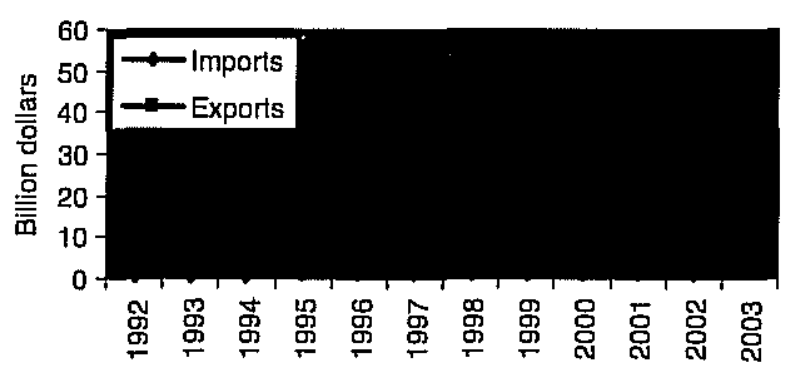

Fig. 2. China's apparel trade

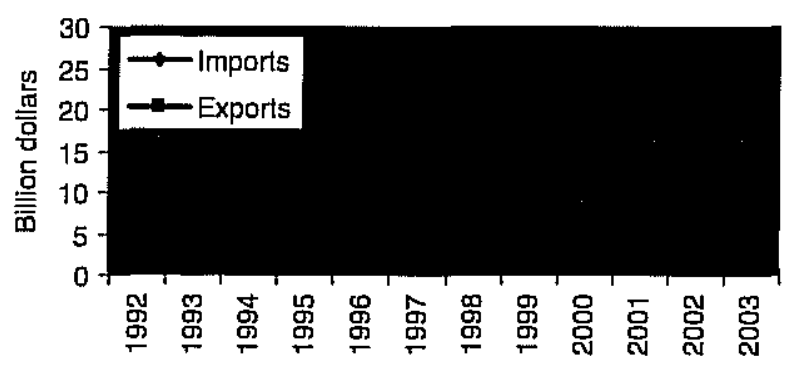

Fig. 3. China's textile trade

ATC (Fig. 1). Compared with the base, world T\&A trade increases by $4-14 \%$ annually, using the midpoint of our efficiency increase estimates. That is, if world T\&A trade were expected to grow $8 \%$ annually in the next 25 years after 2004, then due to the ATC, the new annual growth rate in the model is about $8.5 \%$ on average. The gains in world T\&A trade are about $\$ 20$ billion in the early periods after liberalization and could increase to $\$ 200$ billion in the longer run. Varying the exporters' efficiency gains by 4-5\% (or one standard deviation) had little impact within the 10-year horizon. However, by 25 years the growth of world trade could be seen to vary by 2 percentage points between a high and low efficiency gain scenario as the compounded difference between the scenarios builds (Fig. 1a).

Import protection in any industry typically increases in a cross-section of products as these products become more and more processed. Consistent with this, apparel imports typically face higher tariffs and nontariff barriers worldwide than textile imports. Furthermore, since the MFA quotas were largely in response to growing imports from developing countries, the quotas were typically more restrictive for the labour-intensive apparel products than the more capital-intensive textiles. Thus with the implementation of the ATC, world apparel trade is $9 \%$ higher than in the baseline, while textile trade is only $7 \%$ higher by 2014 .

It is no surprise that the increase in world trade is mainly due to more apparel exports from developing

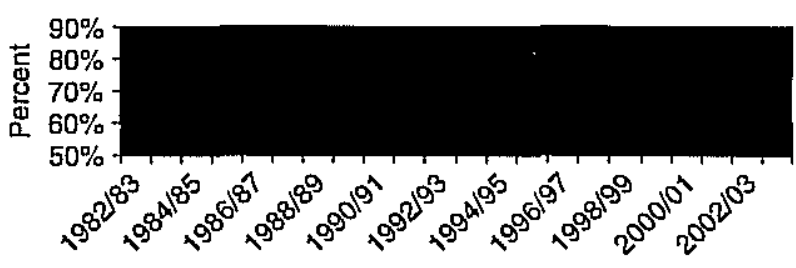

Fig. 4. Cotton's slare of fiber in China's yarn production Source: Chinese government data and USDA estimates.

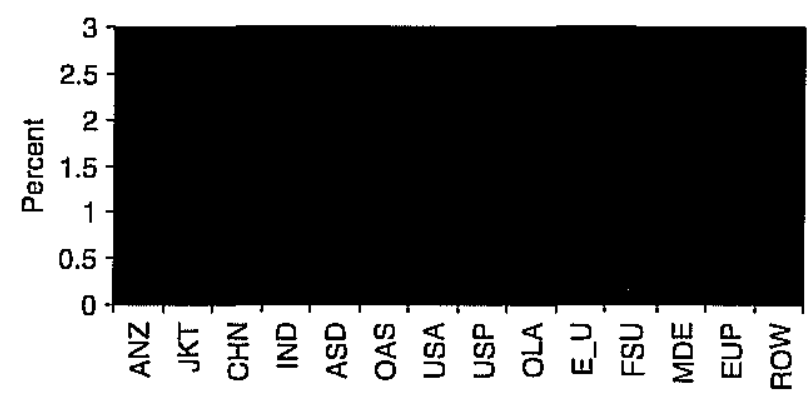

Fig. 5. Welfare gains by region after 25 years

countries, as their exports become more efficient in the model, and the base scenario's trade restraints were greatest for these trade flows. However, the model results also show higher T\&A exports by the industrial countries. When developing countries increase their apparel exports, which are mainly labour-intensive products, their demand for industrial countries' textile products, which are often capital intensive, rises and hence industrial countries' exports also increase. This result suggests that protective policies in the world T\&A trade not only restrain exports of developing countries, but also limit the possible exports of industrial countries and hence hampers the efficiency of world T\&A trade. While liberalization may cause competition between high-income developed and lower-wage developing countries in world T\&A markets, it can also induce interdependency among countries and hence enlarge world trade.

China's apparel exports increase at about the average rate for a developing Asian country (Table 2). They increase slightly more than India's, but slightly less than those of the rest of developing Asia. All the developing countries that did not have preferential trading relations with the United States and the EU see similar increases in apparel exports. India's gains are slightly lower than China's, with an initial increase in exports of $5 \%$ and a $14 \%$ increase by 2014 . Latin America had a 4\% initial increase and a $12 \%$ increase by 2014 . Developing other Asia's exports grew the most, $9 \%$ initially and $20 \%$ by 2014 . Southeast Asia (Indonesia, Thailand and Malaysia) 
Table 2. Apparel: changes in exports due to ATC under alternative growth scenarios

\begin{tabular}{|c|c|c|c|c|c|c|}
\hline & \multicolumn{2}{|c|}{ Average growth } & \multicolumn{2}{|c|}{ High growth } & \multicolumn{2}{|c|}{ Low growth } \\
\hline & 2005 & 2014 & 2005 & 2014 & 2005 & 2014 \\
\hline Clina & 7 & 16 & - & - & - & 15 \\
\hline India & 5 & 14 & - & - & - & 13 \\
\hline Indonesia, Thailand and Malaysia & 10 & 19 & - & 20 & 9 & 18 \\
\hline Other Asia & 9 & 20 & - & - & - & 19 \\
\hline Middle East & 4 & 13 & - & 14 & - & 12 \\
\hline Other Latin America & 4 & 12 & - & - & 3 & 10 \\
\hline Mexico and Caribbean & -3 & -7 & - & - & - & -6 \\
\hline EU Partners & -1 & -4 & - & - & - & - \\
\hline USA & 2 & 1 & - & - & - & - \\
\hline EU Partners & 3 & 1 & - & - & - & - \\
\hline Japan, Korea, and Taiwan & 5 & 3 & - & 2 & - & - \\
\hline
\end{tabular}

Note: - no change from the initial (average) growth scenario.

Table 3. Textiles: changes in exports due to ATC under alternative growth scenarios

\begin{tabular}{|c|c|c|c|c|c|c|}
\hline & \multicolumn{2}{|c|}{ Average growth } & \multicolumn{2}{|c|}{ High growth } & \multicolumn{2}{|c|}{ Low growth } \\
\hline & 2005 & 2014 & 2005 & 2014 & 2005 & 2014 \\
\hline China & 5 & 12 & - & - & - & - \\
\hline India & 4 & 11 & - & - & - & 10 \\
\hline Indonesia, Thailand and Malaysia & 7 & 15 & - & 16 & - & 14 \\
\hline Other Asia & 5 & 12 & - & 13 & - & - \\
\hline Middle East & 3 & 10 & - & 11 & - & - \\
\hline Other Latin America & 4 & 11 & - & - & - & 10 \\
\hline Mexico and Caribbean & -1 & -2 & - & - & - & - \\
\hline EU Partners & 0 & -1 & - & - & - & - \\
\hline USA & 1 & i & - & 0 & - & - \\
\hline EU Partners & 3 & 2 & - & - & - & - \\
\hline Japan, Korea and Taiwan & 6 & 6 & - & - & - & - \\
\hline
\end{tabular}

Note: - no change from the initial (average) growth scenario.

Table 4. China: changes in textiles and cotton due to ATC under alternative growth scenarios

\begin{tabular}{|c|c|c|c|c|c|c|}
\hline & \multicolumn{2}{|c|}{ Average growth } & \multicolumn{2}{|c|}{ High growth } & \multicolumn{2}{|c|}{ Low growth } \\
\hline & 2005 & 2014 & 2005 & 2014 & 2005 & 2014 \\
\hline Apparel exports & 7 & 16 & - & - & - & 15 \\
\hline Apparel imports & 10 & 11 & - & 10 & 9 & - \\
\hline Textile exports & 5 & 12 & - & - & - & - \\
\hline Textile imports & 8 & 9 & - & - & - & - \\
\hline Apparel production & 4 & 6 & - & 7 & - & 5 \\
\hline Textile production & 1 & 3 & - & - & - & 2 \\
\hline Fiber consumption & 1 & 3 & - & - & - & 2 \\
\hline Cotton consumption & I & 2 & па & $\mathrm{na}$ & $\mathrm{na}$ & na \\
\hline Cotton production & 0 & 2 & na & na & na & $\mathrm{na}$ \\
\hline Cotton price & 2 & 6 & na & na & na & na \\
\hline Chemical fiber price & 1 & 3 & $\mathrm{na}$ & na & na & na \\
\hline
\end{tabular}

Note: - no change from the initial (average) growth scenario. 
has a similar increase. China's imports of apparel also increase, but do so from a negligible base (Fig. 2).

The assumption that quota-rents are dissipated has implications for the simulated gains in efficiency and textile production driven by textile trade reform. If exporters captured quota-rents rather than dissipating them, ATC-driven efficiency gains would be smaller. On the other hand, if rents were dissipated, but were larger than expected, then efficiency gains could also be larger. Varying the efficiency growth expected to stem from MFA liberalization by one SD in each direction results in some variation of the simulation results: Southeast Asia's and the Middle East's exports vary slightly from the above results in both the low and high efficiency gain scenarios. In each case, in 2014 exports grow one percentage point more in the high scenario and one percentage point less in the low scenario. Interestingly, Japan, Korea and Taiwan's exports grow slightly slower ( $2 \%$ rather than $3 \%$ ) in the high efficiency gain scenario. Most regions' trade flows are the same in all three scenarios. China is one percentage point lower in the low scenario but the high scenario is the same as the mid-point estimate.

Exports of textiles show a pattern similar to exports of apparel (Table 3): Southeast Asia growing the most, while Mexico and the Caribbean Basin fall the most. China's increase is again about average for a developing Asian country. Among the developed countries, only the Asian developed countries have textile export gains that are substantially higher than their apparel export gains. Korea and Taiwan in particular are more able to exploit their proximity and investment ties to developing Asia to play the role of supplier of the relatively more capitalintensive textiles to neighbouring apparel exporters. Southeast Asia plays a similar role in textiles, but also shows strong gains in apparel exports.

China's textile exports increase $5 \%$ initially and $12 \%$ by 2014 . Textile imports increase more than exports initially, upto $8 \%$. By 2014 however, imports are only $9 \%$ higher than the baseline as China meets more of its expanded needs by increasing textile production. Note that during the 1990 s the value of China's textile imports was somewhat close to the value of its exports, although exports have grown faster more recently (Fig. 3). China is both a source of yarn and fabric for other countries to convert into apparel and a substantial importer of textiles for reprocessing in to exported apparel. The reprocessing trade accounts for a substantial portion of all of China's imports and imports, not just for T\&A.

Varying the efficiency growth results in some variation of these outcomes, although less than in the case of apparel. The results for China are the same in all three scenarios. As with apparel, Southeast Asia varies the most, with textile exports $1 \%$ lower in the low scenario and $1 \%$ higher in the high scenario.

China's textile production rises with trade liberalization (Table 4). China's textile imports rise nearly twice as fast as exports initially with the implementation of the ATC, suggesting that in balance, textile trade might not increase. However, the increase in apparel exports guarantees a need for increased textile production in China. Apparel exports are approximately twice the size of textile exports, while apparel imports are negligible. With the increased demand for inputs into apparel production for both export and domestic demand, China's textile industry increases its output by $1 \%$ initially and by $3 \%$ by 2014 . Varying the global efficiency the growth in China's apparel production changes by 1 percentage point. However, the impact on textile production is smaller: while textile production growth is $1 \%$ point smaller in the low efficiency gain scenario, it is unchanged in the high efficiency scenario.

Growing demand for fiber is unlikely to translate into a one-to-one change in demand for cotton. Globally, cotton's share of fiber use has been declining for decades, and, as noted above, this has also been true of cotton's share of fiber used in yarn production in China (Fig. 4).

The opportunities provided by the implementation of the ATC are expected to induce increased production of both chemical fibers and cotton in China, but, investment can more easily increase capacity for chemical fiber output than it can increase China's the amount of arable land China has to switch into colton production. While total fiber demand increases from the baseline by $1 \%$ initially and $3 \%$ by 2014 , the econometric model of China's agricultural sector indicates that cotton consumption goes up only $1 \%$ initially and by $2 \%$ by 2014 .

Based on those results from the CGE model, the effects on Chinese domestic agricultural production from the partial equilibrium model are presented in Tables 5 and 6. China is able to increase polyester production with a smaller increase in price than cotton, up only $3 \%$ in 2014 . Cotton prices in China, on the other hand, rise $2 \%$ initially, and are $6 \%$ above the baseline by 2014 . As a result, cotton loses a few more percentage points from its share of fiber usage in China's yarn production. Higher prices are in part driven by the need to draw land away from other crops. Production of competing crops falls negligibly (Table 5), and competing crop prices rise, but by negligible amounts.

China's cotton production is $2 \%$ higher than the baseline by 2014 . The Northwest increases the most, 
Table 5. China: changes in agriculture due to ATC

\begin{tabular}{lcr}
\hline & Percent & \\
\cline { 2 - 3 } & 2005 & 2014 \\
\hline Colton production & 0 & 2 \\
Yellow River & 0 & 2 \\
Yangtze River & 0 & 2 \\
Northwest & 0 & 2 \\
Corn production & 0 & 0 \\
Rice production & 0 & 0 \\
Soybean production & 0 & 0 \\
Cotton price & 2 & 0 \\
Corn price & 0 & 0 \\
Rice price & 0 & 0 \\
Soybean price & 0 & \\
\hline
\end{tabular}

since cotton is the region's primary crop. During much of the 1990s, the Northwest was the only region in China where cotton output was expanding. After 1998, the introduction of $\mathrm{Bt}$ cotton led to a rebound in cotton planting in the Eastern Chinese regions. Adoption should have run its course within a few years, and the relationship between Western and Eastern China's cotton production growth should have stabilized by the time the policy changes in this scenario have an impact. Virtually no soybeans are produced in the Northwest, so all the impact on soybeans in this scenario occurs in the Yellow and Yangtze River regions.

China consumes more cotton than it produces, and the implementation of the ATC results in a $2 \%$ increase in both consumption and production. As a result, China increases its cotton imports, but imports only increase $1 \%$ (Table 6). While China is likely to be the world's largest importer during much of these years, a $1 \%$ increase would have a negligible impact on world trade. Likewise, the impact on world prices is negligible in this scenario. China's exports are reduced, but China's cotton exports are so small in any case that this has little bearing.

With WTO accession, China instituted a tariff-rate quota (TRQ) system for cotton. Previously, cotton imports had been in effect subject to licensing, with imports depending on the government's assessment of the needs of the cotton and textile sectors. Starting in 2002, China was obliged by its WTO accession terms to permit at least 819000 tons of imports at a $1 \%$ tariff rate. By 2004, this TRQ had grown to 894000 tons, where it remains, and China is permitted to charge an above-quota tariff upto $40 \%$. However, late in 2003 , China announced a 500000-ton increase in its 2003 quota, and extended shipping dates for cotton purchased under 2003 quota well into 2004. In 2004, China opened still more quota above the TRQ level. Prior to WTO accession, China's government licensed
Table 6. China: changes in cotton due to ATC

\begin{tabular}{lcc}
\hline & Percent & \\
\cline { 2 - 3 } & 2005 & 2014 \\
\hline Cotton production & 0 & 2 \\
Cotton consumption & 1 & 2 \\
Cotton exports & -2 & -4 \\
Cotton imports & 1 & 1 \\
\hline
\end{tabular}

imports equivalent to an even larger share of domestic production than the current TRQ levels imply. As events during 2003 and 2004 indicate, the negotiated TRQ level is not a barrier to an increase in cotton imports driven by freer textile trade. This is particularly true with respect to the results of this analysis since the increases suggested by the model are a fraction of the quota increases actually added by China's government in the recent past.

\section{Discussion}

This study found an impact on China's textile industry due to the implementation of the ATC essentially at the midpoint of the impacts found by previous studies. Most other CGE studies show China's apparel exports expanding by at least $20 \%$ with textile trade reform. However, even studies that suggest larger gains for China's apparel exports than this study have increases in textile output similar to ours. Also, while the results emphasized in this study are lower than $20 \%$, the dynamic results beyond the 10-year horizon are greater. Results of the simulation suggested that expected gains to apparel trade reach $20 \%$ after 14 years and $33 \%$ after 25 years.

In the cotton sector, our analysis indicates a smaller increase in China's cotton imports than found by Fang and Babcock. Most of this difference is due to the smaller expected increase in China's cotton consumption. Fang and Babcock derived a $20 \%$ increase in yarn production expected for China under the post-2004 provisions of the ATC from a review of previous studies. As noted above, most other CGE studies - and the very long run CGE results of this study - show apparel exports expanding by at least $20 \%$ with T\&A trade reform. However, there is not a one-to-one correspondence between apparel export changes and textile production changes. Hertel et al. (1996), Yang et al. (1997) and Francois and Spinanger (2001) all show textile production changes for China 
below $10 \%$ with global textile trade reform. If Fang and Babcock had started from the much lower change in textile output found by this study's CGE analysis, their expected changes in China's cotton imports would be much more similar to those found here.

Finally, while China's sectoral export and output response to $T \& A$ liberalization is about average for a developing Asian country, China does show by far the largest welfare gain (Fig. 5). China's favourable terms of trade and the size of its border protection contributes the most to its welfare gain.

\section{Conclusions}

Assuming equilibrium levels of economic growth and exchange rates throughout the transition path and forecast period, the removal of the MFA quotas and reducing trade restrictions imposed by developing countries would be expected to increase China's apparel production $6 \%$ by 2014 . Textile production there would be $3 \%$ higher by 2014 under these global trade reforms, and as cotton production rises less than the cotton consumption increase necessitated by increased textile production, cotton imports would rise $1 \%$. Our results are consistent with earlier works such as Fang and Babcock (2003), Hertel et al. (1996), Yang et al. 1997 and Francois and Spinanger (2004).

As the MFA phase-out progressed through its conclusion, China's T\&A exports rose not only to the United States and the EU, but also to a number of countries outside the web of preferential access agreements with the United States and the EU. Countries like Australia, Brazil, Norway, Saudi Arabia and Switzerland would actually be expected to import less from China as a result of the ATC's implementation rather than more, but instead, all these countries reported substantially increased imports. China's increased exports to these countries suggests that China's burgeoning T\&A trade is driven by other factors such as exchange rates in addition to the direct and indirect impacts of trade liberalization under the ATC.

\section{References}

Andriamananjara, S., Dean, J. and Spinanger, D. (2004) Trading apparel: developing countries in 2005, 7th Annual Conference on Global Economic Analysis, June 17-19, 2004, Washington, DC.
Baffes, J. and Ajwad, M. I. (2001) Identifying price linkages: a review of the literature and an application to the world market of cotton, Applied Economics, 33, 1927-41.

Chaudhary, J., Mohanty S., Misra S. and Pan S., The effects of MFA quota elimination on Indian fiber markets, Applied Economics (forthcoming).

Cline, W. (1990) The Future of World Trade in Textile and Apparel, Institute for International Economics.

Diao, X. and Somwaru, A. (2000) An inquiry on general equilibrium effects of MERCOSUR - an intertemporal world model, Joumal of Policy Modeling, 22, $557-88$.

Diao, X. and Somwaru, A. (2001) A dynamic evaluation of the effects of a free trade area of the americas - an intertemporal, global general equilibrium model, Journal of Regional Integration, 16, 21-47.

Fang, C. and Babcock, B. (2003) Clina's cotton policy and the impact of China's WTO acession and BT cotton adoption on the Chinese and U.S. cotton sectors. Working Paper 03-WP-322, Center for Agricultural and Rural Development, Iowa State University. January, 2003.

Francois, J., and Spinanger, D. (2001) With rags to riches but then what? Hong Kong's T \& $\mathrm{C}$ industry vs. the ATC and China's WTO accession, The Fourth Annual Conference on Global Economic Analysis, June 27-29, 2001, Center for Global Trade Analysis, Purdue University, West Lafayette, Indiana.

Francois, J., and Spinanger, D. (2004) Liberalizing quotas on textiles and clothing: has the ATC actually worked? 7th Annual Conference on Global Economic Analysis, June 17-19, 2004, Washington, DC.

Frankel, J. A. and Romer, D. (1999) Does trade cause growth?, The American Economic Review, 89, $379-99$.

Hertel, T., Bach, C., Dimaranan, B. and Martin, W. (1996) Growth, globalization, and gains from the Urtugitay round, World Bank Policy Research Working Paper 1614.

Krishna, K. M. and Tan, L. H. (1998) Rags and Riches: Implementing Apparel Quotas Under the Multi-Fiber Arrangement, University of Michigan Press, Ann Arbor.

Krueger, A. O. (1974) The political economy of the rentseeking society, American Economic Review, 64, 291-303.

Nordas, H. (2004). The global textile and clothing industry post the agreement on textiles and clothing, Discussion Paper Number 5, World Trade Organization.

MacDonald, S. (2004) International highlight, in US. Cotton and Wool Situation and Ontlook, CWS-5, United States Department of Agriculture, Economic Research Service.

MacDonald, S., Somwaru, A., Meyer, L. and Diao X. (2001) The agreement on textiles and clothing: impact on U.S. cotton, Cotton and Wool: Situation and Outlook Yearbook (CWS-201), U.S. Department of Agriculture, Economic Research Service, November 2001. 
Pan, S, S. Mohanty, D. Ethridge, M. Fadiga (2004) Structural models of the US and the rest-of-theworld natural fiber market. CER \# 04-03, Cotton Economics Research Institute, Department of Agricultural and Applied Economics, Texas Tech University.

Rivera, S. A., Laurie-Ann A. and Judith D. (2004) Africa Beyond 2005: understanding the impact of eliminating NTBs and tariffs on textiles and clothing, the Sixth Annual Conference on Global Economic Analysis, The Hague, The Netherlands, June 2003.

Romer, P. M. (1984) The origins of endogenous growth, Jounal of Economic Perspectives, 8, 3-22.

Sanford, S. (1989) U.S. Imports of cotton textiles and apparel, Beltwide Cotton Production Research Conferences, Nashville, TN, January 2-7, 1989.
Seale, J., Regmi, A. and Bernstein, J. (2003) International Evidence on Food Consumption Patterns, Technical Bulletin No. 1904, United States Department of Agriculture, Economic Research Service.

Yang, Y., Will, M. and Yanagishima, K. (1997) Evaluating the benefits of abolishing the MFA in the Uruguay round package, in Global Trade Analysis: Modeling and Applications (Ed.) Thomas Hertel, Cambridge University Press, Cambridge.

Yang, Y. and Montfort M. (2004) The end of textiles quotas: a case study of the impact on Bangladesh, 7th Annual Conference on Global Economic Analysis, Washington DC, United States, June 2004.

Yi, Chu-hui, China to Sweep Global Textile Market (2003) Internet-based version of the generally progovernment English-Language daily The Korea Herald. Avialable at http://www.koreahearld.co.kr.

\section{Appendix}

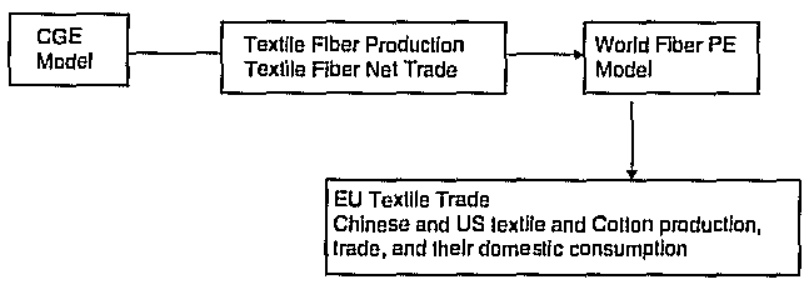

Fig. A1. Linkage between CGE model and PE model 